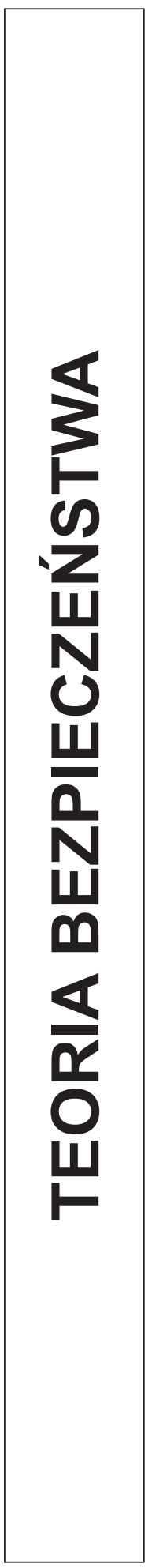





\section{TRANSFORMACJA EUROPEJSKIEGO KOMPLEKSU BEZPIECZEŃSTWA}

Pytania o perspektywy rozwoju Unii Europejskiej towarzyszą jej od momentu powstania. O ile jednak przez dłuższy czas koncentrowały się na problematyce rozwoju procesów integracyjnych (tzw. ,pogłębiania i rozszerzania”: pogłębiania więzi integracyjnych i rozszerzania składu członkowskiego), to od kilkunastu lat coraz częściej dotyczą ich zahamowania lub wręcz odwrócenia. Momentem przełomowym były niewątpliwie debaty nad konstytucją europejską ${ }^{1}$ - która ostatecznie nie weszła w życie (A New, 2007; Presidency, 2007) oraz spory (Phinnemore, 2013) o traktat lizboński². Drugą istotną zmiana, której przejawy możemy obserwować w ostatnich latach, jest coraz silniejsze oddziaływanie czynnika zewnętrznego - środowiska międzynarodowego Unii Europejskiej. Turbulencje na rynkach finansowych, egoizm interesów narodowych, coraz bardziej ekspansywna postawa Rosji, raptownie zwiększające się zagrożenie terroryzmem, dramatycznie narastający problem imigrantów, to zjawiska, które powodują, że środowisko staje się coraz mniej przyjazne i coraz częściej brane pod uwage jako ogranicznik dalszej integracji europejskiej.

Próba naszkicowania narzędzia analitycznego, które usystematyzowałoby rozważania nad możliwymi wariantami rozwoju Unii Europejskiej w wyniku splotu okoliczności wewnętrznych i zewnętrznych jest zatem uzasadniona. Tworzenie, jak to się zwykło teraz mówić, ,scenariuszy” przyszłego ładu europejskiego nie jest, rzecz jasna, niczym oryginalnym; natomiast to, co wydaje się szczególnie kuszące, to wykorzystanie w tym celu podejścia wypracowanego przez wpływowy nurt badawczy, nazywany szkołą kopenhaską ${ }^{3}$, mianowicie teorii kompleksów bezpieczeństwa.

1 „Traktat ustanawiający Konstytucję dla Europy” podpisano 29 października 2004 r. Proces ratyfikacji przez państwa członkowskie został zamrożony w 2005 r. po odrzuceniu traktatu we Francji i Holandii w wyniku referendum; w czerwcu 2007 r. podczas posiedzenia Rady Europejskiej w Brukseli postanowiono zastąpić Konstytucję nowym traktatem modyfikującym dotychczas funkcjonujące.

2 „Traktat z Lizbony zmieniający Traktat o Unii Europejskiej i Traktat ustanawiający Wspólnotę Europejską" (początkowo określany jako Traktat Reformujący) podpisano 13 grudnia 2007 r. Po przejściu procesu ratyfikacji przez wszystkie państwa członkowskie wszedł w życie 1 grudnia 2009 r.

3 Spopularyzowanie tej nazwy przypisuje się Billowi McSweeneyowi, który recenzując wczesne dokonania głównych twórców szkoły - Barry'ego Buzana i Ole'go Wævera - uzasadniał jej użycie widoczną spoistością ich prac (McSweeney, 1996: 81-93). 


\section{UNIA EUROPEJSKA JAKO KOMPLEKS BEZPIECZEŃSTWA}

Według podstawowej definicji kompleksu bezpieczeństwa jest to „grupa państw, których zasadnicze problemy bezpieczeństwa i percepcja tych problemów są powiązane w takim stopniu, iż nie mogą być sensownie rozważane w oderwaniu od siebie" (Kostecki, 2012: 108). Zgodnie z nią, i w rzeczywistości międzynarodowej - a więc traktując kompleksy bezpieczeństwa jako kategorię ontologiczną, i posługując się pojęciem kompleksu jako narzędziem analitycznym, możemy zidentyfikować ich granice i opisać strukturę, a następnie charakteryzować ich funkcjonowanie i ewolucję. Twórcy szkoły kopenhaskiej zastosowali tu swoistą hybrydowość w sposobie myślenia. $\mathrm{Z}$ jednej strony, kompleksy bezpieczeństwa to koncepcja silnie zakotwiczona w tradycyjnym rozumowaniu realistycznym - konstytuuje je nie tylko bliskość geograficzna państw i zachodzące między nimi współzależności, dzielone przez nie wzorce sympatii i antypatii, uleganie oddziaływaniu światowych ośrodków potęgi, ale także, a nawet przede wszystkim, postrzegane zagrożenia i sposoby przeciwstawienia się im, a więc argument z obszaru intensywnie rozwijanego podejścia konstruktywistycznego. Używając coraz popularniejszej terminologii można powiedzieć, że chodzi tu o splot procesów sekurytyzacji i desekurytyzacji, zachodzących w tych państwach, nie tylko w sektorze wojskowo-strategicznym i polityczno-dyplomatycznym, ale i w całościowo ujmowanej sferze zagadnień społeczno-ekonomicznych (Buzan, 2003).

Czy z tego punktu widzenia Unia Europejska stanowi kompleks bezpieczeństwa? Niewątpliwie tak. Choć współcześnie bywa traktowana wyłącznie jako instytucja ekonomiczna ${ }^{4}$ - przykładem może być niedawna wypowiedź cenionego niemieckiego politologa Michaela Brzoski: „[UE] pozostaje gospodarczą organizacją. W sprawach bezpieczeństwa i pokoju, to NATO jest ważne, a w sprawach gospodarczych to jest UE" (With Ukraine, 2015) - to u jej powstania legły idee polityczne - miała być wspólnotą gwarantującą zachowanie pokoju i umacnianie bezpieczeństwa w Europie. Lapidarnie ujęli to autorzy oficjalnej historii Unii zamieszczonej na jej stronach internetowych: „Unię Europejską utworzono po to, aby położyć kres krwawym wojnom, wybuchającym często pomiędzy sąsiadującymi krajami, z których najstraszliwszą była II wojna światowa" (1945-1959, 2015). Podobne sformułowania można znaleźć w wypowiedziach „ojców-założycieli” Unii i dokumentach z tamtego okresu; często cytowane jest na przykład to z Deklaracji Schumana proponującej utworzenie pierwszej europejskiej wspólnoty - Węgla i Stali (EWWiS): „Solidarność produkcji, która się w ten sposób nawiąże, ukaże, że wszelka wojna między Francją a Niemcami jest nie tylko nie do pomyślenia, ale i fizycznie niemożliwa" (Deklaracja, 2015). Podobnie późniejsze przedsięwzięcia, poszerzające i intensyfikujące współdziałanie państw członkowskich w sferze ekonomiczno-społecznej, wyrastały z przekonania o tym, że korzyści ze współpracy, obojętnie bezwzględne czy relatywne, przewyższają ewentualne zyski, jakie można by odnieść wracając do tradycyjnej power politics, napędzają proces europeizacji rozumianej jako adaptacja narodowej kultury bezpieczeństwa do specyficznych wymogów integracyjnych (Rieker, 2006: 1-50) i ułatwiają przeciwsta-

\footnotetext{
4 Chciałoby się dodać, zwłaszcza w optyce tych, którzy w Unii widzą jedynie źródło funduszy pomocowych.
} 
wienie się zagrożeniom i podjęcie wyzwań płynących spoza unijnych granic. W tej ostatniej dziedzinie pomocna była też europejska polityka rozszerzania, do niedawna postrzegana jako najbardziej skuteczne narzędzie Unii w stosunkach zewnętrznych oraz polityka sąsiedztwa (ang. European Neighbourhood Policy - ENP). Symbolicznym ukoronowaniem zaś podobnego podejścia do roli Unii Europejskiej stało się przyznanie jej w 2012 r. Pokojowej Nagrody Nobla za to, że - jak głosiło oficjalne oświadczenie - „od ponad sześciu dziesięcioleci przyczyniała się do rozwoju pokoju i pojednania, demokracji i praw człowieka w Europie" (The Nobel, 2012).

Wraz z postępowaniem integracji europejskiej, jej instytucjonalizacją, powiększaniem jej obszaru, potwierdzały się też „hybrydowe” założenia pozwalające uznać Unię za kompleks bezpieczeństwa. Kolejne etapy jej ewolucji oznaczały bowiem przemiany w zbiorze czynników konstytuujących kompleks: zagrożenia dla bezpieczeństwa traciły wewnętrzny charakter, wynikający z terytorialnej bliskości członków i przesuwały się na zewnątrz, stanowiąc wyraz obaw przed ,innością" środowiska i oddaloną potęgą. Pojęcie owej „inności” (ang. othering), nasiliło się w europejskim dyskursie w XXI wieku na tle ogłoszonej przez Amerykę wojny z terroryzmem i debat nad kondycją demokracji w świecie, i odnoszone było do dość ugruntowanego skądinąd wzorca postępowania nakazującego różnicować relacje ze „swoimi” - w tym przypadku tymi, którzy podzielają europejskie liberalne wartości, a tymi, którym są one obce (Joenniemi, 2007: 127-148). Zagadnienia percepcji zagrożeń zewnętrznych - właśnie tych napływających z oddalonych obszarów, jak proliferacja nuklearna, jak i tych, które w dużej mierze wynikają z postrzeganej odmienności, czy wręcz obcości - jak terroryzm islamski, stały się istotnymi - dla niektórych badaczy wręcz kluczowymi determinantami europejskiego kompleksu bezpieczeństwa (Demurtas, 2014). W ramach szkoły kopenhaskiej, nieco żonglując pojęciami, już wcześniej opisywano poszczególne fazy tego procesu jako sekwencję sekurytyzacji - gdy strach przed kolejną wojną na kontynencie (ang. insecurity - brak bezpieczeństwa, niepewność) skłonił sześć krajów europejskich do podjęcia działań integracyjnych; desekurytyzacji - będącej wynikiem przekonania, że sukcesy integracji wykluczyły powrót do stosowania siły w stosunkach wzajemnych integrujących się państw (ang. security - poczucie bezpieczeństwa); „nie-bezpieczeństwa” (ang. asecurity), przejściowego stanu, w którym kwestie bezpieczeństwa zniknęły z agendy działań integracyjnych w wyniku fałszywego, jak się wkrótce miało okazać, przekonania, że egzystencjalne problemy w stosunkach państw członkowskich zostały trwale rozwiązane, na kontynencie postępuje odprężenie, a koniec zimnej wojny znosi rywalizację supermocarstw; resekurytyzacji - kiedy problemy bezpieczeństwa powróciły na porządek dnia dyskusji europejskich w warunkach zaawansowanych powiązań integracyjnych (ang. security after sovereignty) (Wæver, 1998: 69-118).

Szczególnie użyteczną zaletą i chyba najciekawszą funkcją teorii kompleksów bezpieczeństwa są jej zdolności prognostyczne - funkcja predyktywna. Polega ona na wskazaniu przesłanek pozwalających wnioskować o możliwych przekształceniach danego kompleksu i określa ich potencjalny zakres, za punkt wyjścia przyjmując prostą kombinację zmian struktury i granic kompleksu. Dostępne w tym zakresie warianty to: zachowanie status quo - kiedy zachodzące przeobrażenia nie naruszają zasadniczej struktury ani granic kompleksu, poprzez transformację wewnętrzną - gdy prze- 
kształcenia struktury nie wymuszają zmiany granic kompleksu oraz transformację zewnętrzną - zmiany struktury kompleksu są wynikiem zmiany jego granic, aż po rozpad kompleksu zachodzący wówczas, gdy jego wewnętrzna dynamika zostaje podporządkowana zmianom dziejącym się w otoczeniu (Kostecki, 1994).

Rozwój badań zmierzających do wypełniania funkcji predyktywnej przebiegał od kreślenia różnych wariantów ewolucji europejskiego kompleksu bezpieczeństwa (Buzan, 1990; Kostecki, 1996) przez próbę syntezy regionalnego spojrzenia na całość problemów międzynarodowego bezpieczeństwa (Buzan, Wæver, 2003), wspartego przekonaniem o postępującej decentralizacji systemu międzynarodowego (Barry, 2009), po analizę wyzwań, jakie dla teorii kompleksów bezpieczeństwa stanowi brak sukcesów $\mathrm{w}$ budowie ponadregionalnych struktur bezpieczeństwa z jednej strony (Intersecting, 2014), a z drugiej - ambicje wzniesienia współpracy w dziedzinie bezpieczeństwa na wyższy poziom i wykreowania wspólnot bezpieczeństwa, w których więzi wzbogacone są o podzielane wartości (Rieker, 2006: 51-62; Laporte, 2012). W zmienionej sytuacji międzynarodowej, w obliczu przejawów załamywania się europejskiej solidarności, najwyższa pora powrócić do tej pierwszej kwestii: perspektyw zmian nadciagających w europejskim kompleksie bezpieczeństwa. Przy czym, chodzi tu nie o prezentację bardzo dynamicznych wydarzeń, na bieżąco omawianych w popularnych źródłach ${ }^{5} \mathrm{i}$ będących przedmiotem zaostrzających się sporów, także w naszym kraju, lecz o propozycję usystematyzowania wachlarza możliwości, jakie się przed europejskim kompleksem otwierają, opartą na założeniach teorii kompleksów bezpieczeństwa ${ }^{6}$.

Wyjściowe założenia tej teorii mówią, że przeobrażenia kompleksu bezpieczeństwa - jako odpowiedź na zmiany zachodzące wśród konstytuujących go czynników - polegają na przekształceniach jego struktury (wewnętrzny wymiar transformacji) i przekształceniach $\mathrm{w}$ jego relacjach $\mathrm{z}$ otoczeniem (zewnętrzny wymiar transformacji). W odniesieniu do kompleksu bezpieczeństwa stanowionego przez Unię Europejska, w tym pierwszym przypadku chodzi naturalnie o tempo, zakres i postrzegany lub zamierzony cel („finał”) procesów integracji bądź dezintegracji. W przypadku drugim, ze względu na ukształtowany po drugiej wojnie światowej układ sił (,rozkład potęgi”), czynnikiem, który jednoznacznie traktowany był jako zewnętrzna determinanta kompleksu, pozostawał Związek Radziecki, a po zakończeniu zimnej wojny, jako jego spadkobierca - Rosja, ściślej: jej dążenia do odbudowy mocarstwowej pozycji oraz ocena szans i konsekwencji takich działań. Oczywiście, na stan i poczucie bezpieczeństwa państw Unii Europejskiej wpływał i wpływa ogromny zbiór wielu innych czynników zewnętrznych, ale rygorystycznie pojmowana teoria nakazywała interpretować je w kategoriach tworzenia się w warunkach pozimnowojennych całego „łańcucha” kompleksów regionalnych, wyłaniania subkompleksów i rozważania zasadności pojęcia globalnego

5 Można tu wskazać np.: oficjalne portale europejskiej: European Union Newsroom (EUROPA) i EurActive (EurActiv_com), niezależny, ale kojarzony z ,eurosceptykami” magazyn on-line EUobserver (EUobserver_com), think-tanki Centre for European Policy Studies (Centre) i European Policy Centre $(E P C)$ oraz sekcję europejską kontrowersyjnego amerykańskiego ośrodka analitycznego Stratfor (Europe) i europejskie kolumny gazety „Financial Times” (World) uchodzącej za najbardziej poczytne źródło dziennikarskie.

${ }^{6}$ W dalszych rozważaniach wykorzystuję schemat zarysowany we wcześniejszym artykule (Kostecki, 2014: 49-53). 
kompleksu bezpieczeństwa (Lake, Morgan, 1997; Buzan, Wæver, 2003). Nie znajdowano też uzasadnienia dla włączenia do rozważań w tym kontekście Stanów Zjednoczonych, z uwagi na niepomiernie większą skalę ich interesów bezpieczeństwa i przesuwanie uwagi poza Europę (Stewart-Ingersoll, Frazier, 2012: 128-129).

\section{TRANSFORMACJA WEWNĘTRZNA}

Wymiar pierwszy, wewnętrzny, w toczonych właściwie od momentu powstania Unii Europejskiej debatach, obejmuje trzy warianty przebiegu wypadków: poza dalszym postępem, także zatrzymanie i upadek integracji. Skądinąd świadczy to o swoistej niedojrzałości Unii jako instytucji i projektu politycznego, który nie doprowadził - nie mógł doprowadzić? - do przekroczenia punktu granicznego, za którym nie ma już od integracji odwrotu. Co prawda, można wskazać w dekadzie lat 90. ubiegłego wieku głosy polityków, na fali pozimnowojennego entuzjazmu uznające zasadnicze problemy bezpieczeństwa na kontynencie za rozwiązane w wyniku upadku „realnego socjalizmu" w Europie Środkowo-Wschodniej, zjednoczenia Niemiec, przyjęcia Paryskiej Karty Nowej Europy, rozwiązania Rady Wzajemnej Pomocy Gospodarczej i Układu Warszawskiego, likwidacji Związku Radzieckiego, słabnącej potęgi Jelcynowskiej Rosji i wycofania wojsk rosyjskich z państw byłego Układu Warszawskiego. Szybko jednak ucichły one, tak pod wpływem wybuchu wojen w byłej Jugosławii, jak i - a może przede wszystkim - nowych intencji, nowych „opcji” i często nieskrywanej rezerwy wobec najbardziej ambitnych planów integracyjnych, wnoszonych przez państwa, które pojawiały się w Unii w wyniku kolejnych fal rozszerzenia. Warto przypomnieć, że mało znanym impulsem do uformowania się szkoły kopenhaskiej i kojarzenia coraz bardziej wyrafinowanej teorii kompleksów bezpieczeństwa z duńskim ośrodkiem badawczym były toczone $\mathrm{w}$ tym kraju debaty nad ryzykiem dla tożsamości narodowej (Dania przecież graniczy z Niemcami, a jej potencjał - jej „power” - w stosunku do niemieckiego jest wielokrotnie mniejszy) i pomysły, by - gdyby doszło do różnicowania się sfer integracji, Dania, wraz z całą Skandynawią, zadbała o swoją odrębność kulturową. Gdy więc nie udawało się doprowadzić do zmaterializowania dalej posuniętych ambicji - wspomniane fiasko konstytucji europejskiej jest tu narzucającym się przykładem - coraz częściej padało hasło ever-closer union - budowania „coraz ściślejszej unii” i pojawiały się metafory jak ta, że zbyt wolna jazda rowerem musi skończyć się upadkiem..., a zatem dla podtrzymania integracji europejskiej trzeba ją cały czas wprawiać w ruch, występować z nowymi inicjatywami.

Niemniej jednak przebieg wypadków spowodował, że poważniejsze, przemyślane, całościowe propozycje wejścia na wyższy szczebel integracji państw europejskich - np. przekształcenia Unii Europejskiej w federację - w praktyce ucichły. Przysłowiowym łabędzim śpiewem była chyba inicjatywa zrodzona w mającym swoją siedzibę w Los Angeles think-tanku pn. Instytut Berggruena, który swoją misję definiuje jako „rozwijanie fundamentalnych idei, a poprzez nie, kształtowanie instytucji politycznych i społecznych dla XXI wieku" (Berggruen). Zgromadzona przez instytut grupa ekspertów złożona tak ze znanych polityków jak Tony Blair, Jacques Delors, Romano Prodi, Gerhard Schroeder, a z Polski Marek Belka, jak i akademików: Nialla Ferguso- 
na, Anthony'ego Giddensa, Josepha Stiglitza, wydyskutowała jako najodpowiedniejszy dla Unii model federacyjny zaczerpnięty z doświadczeń szwajcarskich, oparty na rządzie silnym choć z ograniczonymi kompetencjami (strong but limited central government), zdolny do pogodzenia tak wielu lokalnych odmienności jak to tylko możliwe. I o ile w środowisku badaczy artykuł z wynikami dyskusji (Berggruen, Gardels, 2013: 134-142) spotkał się z życzliwym zainteresowaniem, to podobne hasło, rzucone przez ówczesnego przewodniczącego Komisji Europejskiej José Manuela Barroso na forum Parlamentu Europejskiego: „Musimy zmierzać w kierunku federacji państw narodowych. To jest to, czego potrzebujemy. To jest nasz horyzont polityczny" (Barroso, 2012: 11) zostało już przez komentatorów uznane za „bombę federacyjną” (F-bomb) (Should, 2012), która tylko może przyspieszyć działania dezintegracyjne ze strony rosnących w siłę przeciwników integracji.

Obecnie taki wariant rozwoju jawi się jako całkowicie nierealistyczny, choć nie niemożliwy. Nadzieje na triumf integracji europejskiej: wyjście z kryzysu w strefie euro i kryzysu finansów publicznych; umocnienie jednolitej struktury wewnętrznej i instytucjonalnej, działającej z poszanowaniem zasady subsydiarności, ale dysponującej skutecznymi sankcjami wobec naruszających normy europejskie i dysponującej legitymacją społeczną; urzeczywistnienie trwałej, powszechnie aprobowanej i wszechstronnej współpracy w dziedzinie polityki zagranicznej, bezpieczeństwa i obrony; ochronienie liberalnych wartości i otwartości Unii Europejskiej - płyną nie tyle z postępowania elit politycznych motywowanych doraźnym interesem i przysłowiowymi słupkami poparcia w sondażach. Są raczej odzwierciedleniem zachowania przedstawicieli młodszej generacji „zaangażowanych obywateli”, głoszących: „Dla mojego pokolenia formatywnym doświadczeniem była integracja Polski z Unią Europejską. Oznaczała ona nie tylko skok cywilizacyjny, który - jestem przekonany - bez Unii nie udałby się w Polsce, ale również poczucie przynależności do klubu, który zapewniał bezpieczeństwo polityczne, ekonomiczne, pewność reguł gry i tym samym relatywnie przewidywalną przyszłość" (Nowak, 2016).

Drugi wariant, polegający na obronie idei, które legły u podstaw integracji europejskiej choćby w ograniczonym terytorialnie (i mentalnie!) zakresie i podzieleniu się krajów unijnych na kilka kręów o różnym stopniu i zakresie integracji - czyli triumfie Europy wielu prędkości, albo, zgodnie z inną pojawiającą się terminologią, odnotowaną nawet w oficjalnym glosariuszu Unii Europejskiej, „Europy zmiennej geometrii”, „Europy à la carte” (Glossary), czy też „Europy koncentrycznych kręgów”, to opcja rozważana tak przez „klasyków” teorii kompleksów bezpieczeństwa, jak i badaczy wywodzących się z innych nurtów. W tym pierwszym przypadku użyteczne są uwagi o malejącym poparciu dla charakterystycznej dla Unii jako kompleksu bezpieczeństwa centralizacji, rozumianej jako oddelegowanie części kompetencji państw do instytucji międzynarodowych; pogłębianiu się podziału na centrum - „stare” kraje członkowskie i „peryferia” - kraje, które przystapiły do Unii w ostatnim okresie (a więc przede wszystkim te $\mathrm{z}$ obszaru Europy Środkowo-Wschodniej); słabnięciu jądra instytucjonalnego Unii, które przez lata było czynnikiem integracji (Wæver, 2005: 151-174). Podobnie inspirują nowsze, paradygmatyczne rozważania o „kontrolowanej dezintegracji” jako ,jedynym sposobie uratowania zasadniczej idei zjednoczonej Europy" (Ławniczak, 2014: 37). Jeśli tak jest, dowodzą z kolei przedstawiciele 
nurtu scjentystycznego, to pryncypialne pytanie brzmi nie dlaczego następuje zróżnicowanie modeli integracyjnych, ale dlaczego Unia do tej pory nie stała się bardziej podzielona? Odpowiadając na nie, z użyciem teorii gier i innych zmatematyzowanych metod podpowiadają, że w obszarze efektów integracji europejskiej, rozumianej jako różnego rodzaju dobra, od ,prywatnych” - np. dostępu do środków finansowych, któremu towarzyszy rywalizacja, po ,publiczne” - jak działania ze sfery zapewniania pokoju, które dotyczą wszystkich, znajduje się przestrzeń, w której ograniczanie konsumentów dóbr i różnicowanie zakresu członkostwa może przynieść wyraźne korzyści (Hvidsten, Hovi, 2015: 3-22).

W istocie, Unia Europejska jest tworem zróżnicowanym bardziej niż się na co dzień pamięta. Zestawienie udziału poszczególnych państw w strefie Schengen i strefie euro, zaangażowania w poszczególne dziedziny polityki unijnej i sformalizowane związki między krajami (jak Grupa Wyszehradzka czy Rada Nordycka), daje obraz już występujących różnic. Możliwy dalszy podział Europy na różnorodne bloki może zaś polegać - zdaniem ośrodka Stratfor - na uwydatnieniu się ,jądra” integracji, czyli - oczywiście - sześciu jej pierwotnych członków, utrzymujących między sobą otwarte granice i wspólną walutę; bloku ,handlowego”, dla którego priorytetem będzie utrzymywanie współpracy gospodarczej z Niemcami przy jednoczesnym ograniczaniu swobodnego przepływu osób i ostrożności wobec antagonizowania Rosji - analitycy widzą w tej roli Czechy, Węgry, Rumunię, Bułgarię i Słowację; grupę „twardego” bezpieczeństwa - Polskę i państwa bałtyckie, dla których naczelnym zadaniem będzie, przeciwnie, poszukiwanie sojuszników i sposobów przeciwstawienia się zagrożeniu płynącemu ze strony Rosji; wreszcie osobny blok skandynawski - naturalnie odrębne ugrupowanie, wykorzystujące więzi historyczne, tradycje zaawansowanej współpracy i bliskie stosunki międzyludzkie (Europe, 2016).

Rzeczywiście, taki przebieg wydarzeń, z punktu widzenia całego kontynentu, może doraźnie okazać się atrakcyjny jako sposób na uniknięcie rozwiązań drastycznych i żegnania się z europejską integracją. Z drugiej strony, może to oznaczać osiagnięcie punktu granicznego integracji à rebours: definitywnego przełamania tabu rozwiązań niekompletnych, ugruntowania przekonania, że integrację nie tylko można hamować, ale wręcz należy poddać rozmaitym ograniczeniom, kolejne kroki w tym kierunku i w efekcie powstanie mechanizmu ever-looser union - coraz luźniejszej unii (Patrick, 2016). Jednak luźniejsza Unia to słabsza Unia, słabiej radząca sobie z ponadnarodowymi zagrożeniami, bez szans na odegranie globalnej roli. Tym samym, jest to opcja prowadząca w dłuższym horyzoncie do rezultatów zbliżonych do trzeciego, logicznie wynikającego wariantu przebiegu wypadków: zdecydowanego cofnięcia procesów integracyjnych, ograniczenia współpracy do wybranych dziedzin gospodarki i ogólnej porażki ,projektu europejskiego" - czyli triumfu renacjonalizacji.

Ten wariant w ciągu ostatnich kilku lat stał się lawinowo narastającym motywem debat politycznych, a w ślad za nimi szeroko wkroczył do sfery nauki. Inwentaryzacja pojawiających się w tych debatach wątków, niewątpliwie pouczająca, w formacie artykułu jedynie zamąciłaby obraz. Z punktu widzenia teorii kompleksów bezpieczeństwa, istota rzeczy sprowadza się bowiem do następujących zjawisk:

1. Powrotu do sytuacji przez realistów politycznych określanej jako ,anarchiczny system polegania na sobie" (ang. anarchic self-help system), w której każde państwo 
dba przede wszystkim o własne interesy i każde podejrzewa inne o wrogie zamiary. W takim systemie główną rolę przejmują państwa, które na pierwszy plan wysuwają starania o zyski relatywne, nie absolutne, czyli zależy im przede wszystkim na tym, aby ktoś inny nie zyskał więcej (Hyde-Price, 2007).

2. Dominujący dyskurs ulega postępującej stereotypizacji. Występujące wzorce sympatii i wrogości prezentowane są w terminach egoistycznych potrzeb, niespełnionych aspiracji i prób narzucania sposobu postrzegania świata. Narastająca fala migracyjna, przed którą już wcześniej ostrzegali eksperci, obrazowana jest jako kryzys uchodźczy, lecz propozycje jego zahamowania i odwołania do europejskiej solidarności coraz powszechniej uznaje się za kolidujące z zasadą suwerenności narodowej (Patrick, 2015).

3. W każdej z ról przypisywanych Unii Europejskiej postrzeganie rzeczywistości oscyluje w stronę samospełniającej się przepowiedni. Unia jako system zarządzania transponujący narodowe preferencje we wspólny interes przestaje funkcjonować; Unia jako wspólnota wartości traci swoją przyciagającą moc; Unia jako organizator współdziałania znoszącego impulsy do stosowania przemocy zmierza do ograniczenia wzajemnych współzależności, społecznego przenikania i strategicznych interakcji; Unia jako organizacja gospodarcza jawi się jako pogrążona w kryzysie walutowym, mimo sukcesywnych kroków naprawczych; Unia jako siła prawodawcza i autorytet obywatelski przestaje być wzorcem do naśladowania; Unia jako regionalny rozjemca i dostarczyciel pomocy humanitarnej i rozwojowej ma coraz mniej woli by wypełniać tę rolę w praktyce. Rezultatem staje się wielopłaszczyznowy kryzys Unii Europejskiej: kryzys przywództwa i niezbędnej dla jego sprawowania wizji; kryzys gospodarczy, widoczny nie tylko w skali zbiorowej (euro), ale problemów poszczególnych krajów; kryzys instytucjonalny, polegający nawet nie tyle na rozrastaniu się biurokracji, pochłaniającej coraz więcej środków, co na przewlekłości procesów decyzyjnych, komplikacji procedur, braku przejrzystości w prowadzeniu kluczowych negocjacji (vide rokowania ze Stanami Zjednoczonymi w sprawie TTIP); wreszcie, kryzys aksjologiczny, zarówno w sferze promowanych wartości, sposobów uprawiania polityki, jak i - typowe last but not least-budowaniu „europejskiego patriotyzmu", niezbędnego w erze narastania narodowych skrajności (Toje, 2010; Góralczyk, 2014: 163-180; Wojtaszczyk, Nadolska, Czub, 2014: 13-21).

Kwintesencją zachodzących zmian stała się zaś obecność w Europarlamencie rosnącej liczby posłów otwarcie wypowiadających się przeciwko Unii Europejskiej, co jeszcze całkiem niedawno wydawało się nie do pomyślenia. Wraz z restauracją pojęcia suwerenności i suwerennych prerogatyw władzy oraz sukcesów populizmu w coraz większej liczbie państw, w połowie 2016 roku triumf renacjonalizacji staje się coraz bardziej realistycznym wariantem ewolucji europejskiego kompleksu bezpieczeństwa.

\section{TRANSFORMACJA ZEWNĘTRZNA}

Podstawowym wyznacznikiem zewnętrznego wymiaru transformacji kompleksu europejskiego, w ujęciu tradycyjnym, jest ewolucja możliwości, jakie otwierają się przed Rosja, aby trwale i skutecznie odbudować swoją wielkomocarstwową pozycję. 
To ostatnie zagadnienie ze zrozumiałych względów od lat cieszy się powodzeniem wśród badaczy ${ }^{7}$, w tym miejscu zaś jest istotne o tyle, o ile wpływa na rozkład potęgi w bezpośrednim otoczeniu Unii Europejskiej i postrzeganą przez jej członków wzajemną sympatię lub wrogość. W odróżnieniu od okresu, w którym tworzono podstawy teorii kompleksów bezpieczeństwa, obecnie alternatywa: Rosja „słaba” bądź „silna” została w znacznym stopniu rozstrzygnięta na korzyść wariantu, w którym Rosja odbudowuje swoją potęgę. Na ile jest to proces trwały, mający mocne, materialne podstawy, a na ile rezultat ekspansywnej polityki skutecznie oddziałującej na percepcję członków Unii, to znów osobne zagadnienie (Nygren, 2008; Snetkov, 2015). Chodzi natomiast o to, że wyjściowa matryca transformacji europejskiego kompleksu bezpieczeństwa coraz wyraźniej zawęża się do dwóch opcji: zestawienia „silnej” Rosji z podzieleniem się krajów unijnych na kilka ugrupowań - triumfem „Europy wielu prędkości”, albo powrotem do egoistycznej, narodowej polityki państw europejskich - triumfem renacjonalizacji.

Za pierwszą z nich, poza czynnikami wynikającymi z wewnętrznego wymiaru transformacji kompleksu, przemawiają przesłanki wynikające z zachowania Rosji, wykorzystującej okazje, by dzielić państwa unijne. Obawy przed pokusą specjalnych stosunków niemiecko-rosyjskich wyrażane są od dawna przez największe autorytety dyplomacji światowej (Kissinger, Billington, 2001), a to tylko jeden z przykładów możliwych wydarzeń, które napędzane będą zmianami w składzie członkowskim Unii, a nawet samą perspektywą takich zmian oraz coraz szerszą przestrzenią dla projekcji rosyjskiej potęgi: na Bliskim Wschodzie, w oporze przeciw amerykańskiej tarczy antyrakietowej i przesuwaniu jednostek NATO na wschód, czy nawet w polityzacji historii jako instrumencie wybiórczego oddziaływania Rosji na swych zachodnich sąsiadów. Za możliwym zbiegnięciem się sukcesów w odbudowie potęgi rosyjskiej z renacjonalizacją polityki państw europejskich stoją natomiast procesy pojawiające się w kolejnych krajach wszystkich rejonów kompleksu europejskiego, z czołowym państwem ,jądra" europejskiej integracji - Niemcami - włącznie, świadczące o tym, że zasadniczy zwrot w nastrojach dopiero Unię Europejską czeka. W sondażu przeprowadzonym w początkach 2016 r., średnio co trzeci mieszkaniec Unii deklarował, że gdyby w jego kraju odbywało się referendum, to głosowałby za opuszczeniem Unii, a głosować za pozostaniem zdecydowana była niecała połowa (Half, 2016).

W obu tych wariantach - związanych z rozwojem sytuacji w Rosji - poszczególne kraje, choć w różnym stopniu, traciłyby osiągniętą w rezultacie postępów integracji pozycję, a nowi członkowie także korzyści będące skutkiem ,ppowrotu do Europy”, w tym gwarancje bezpieczeństwa politycznego i gospodarczego wynikające z uczestnictwa $\mathrm{w}$ jednolitych strukturach integracyjnych. Zachodzące $\mathrm{w}$ świecie przemiany sugerują ponadto użyteczność - poznawczą i praktyczną - uwzględnienia w analizie zewnętrznego wymiaru transformacji europejskiego kompleksu bezpieczeństwa obecnej ewolucji szerszego ładu międzynarodowego.

Z punktu widzenia teorii kompleksów bezpieczeństwa chodzi tu przede wszystkim o zmiany zachodzące w środowisku międzynarodowym, w którym Unia Europejska

7 Najnowsze prace omawia Cristian Nitoiu z London School of Economics (Nitoiu, 2016). 
jako całość sukcesywnie traci rolę wielkiego mocarstwa (Bengtsson, 2010), czy też światowej potęgi, czy w jeszcze innej terminologii ,globalnego aktora”, natomiast do osiagnięcia takiego statusu konsekwentnie aspiruje Rosja. Oba te procesy odbywają się w warunkach, do których coraz bardziej pasuje opinia: ,świat przestawił się z antyamerykanizmu na poamerykanizm", w których do głosu dochodzi nieamerykańska i niezachodnia „reszta świata” (Zakaria, 2008; Kuźniar, 2016). „Świat poamerykański” to zatem nowy porządek międzynarodowy, w którym procesy globalizacji postępują równolegle do rysujących się podziałów wewnątrz „cywilizacji zachodniej” - „Amerykanie są z Marsa a Europejczycy z Wenus", stosunki międzynarodowe nasycają się huntingtonowskim komponentem tożsamości i kultury, a status wielkiego mocarstwa coraz lepiej pasuje do kolejnych państw, z Chinami na czele. W takim świecie miejsce Unii Europejskiej jako „bieguna przyciagania” i dostarczyciela wzorców coraz skuteczniej będą zajmować nowe mocarstwa regionalne, które, jak zauważono już dekadę temu, mogą decydować się na „pomijanie” Zachodu i nawiązywanie więzi w swoim własnym gronie. Problemem, z którym być może przyjdzie się zmierzyć, może okazać się - w czasach, w których triumfy święci (re)nacjonalizacja i rozpadają się struktury międzynarodowe, przechodzenie od takiego czy innego świata wielobiegunowego do świata „bezbiegunowego”, pozbawionego jakiegokolwiek „centrum przyciagania” i dominującego modelu politycznego, w którym rywalizacja toczyć się będzie nie wokół tego, kto określa „reguły gry”, ale co stanowi o ich legitymizacji, „świata należącego do nikogo" (Kostecki, 2012: 48-52), w którym państwa europejskiego kompleksu bezpieczeństwa, zwłaszcza te średnie i mniejsze, które w minionym ćwierćwieczu najwięcej korzystały z potęgi, jaką daje członkostwo w nim, będą musiały polegać na własnych siłach.

\section{Bibliografia}

1945-1959. Europa w dobie pokoju - poczatki wspótpracy (2015), „Historia Unii Europejskiej”, 19.10.2015, http://europa.eu/about-eu/eu-history/index_pl.htm (19.05.2016).

A New Treaty and Supplementary Protocols (2007), Explanatory Memorandum, Action Committee for European Democracy, Brussels.

Barroso J. M. D. (2012), State of the Union 2012 Address, 12.09.2012, Speech 12/596, European Commission.

Barry Buzan on International Society, Securitization, and an English School Map of the World (2009), Theory Talk \#35: Barry Buzan, 19.12.2009, http://www.theory-talks.org/2009/12/theorytalk-35.html (19.05.2016).

Bengtsson R. (2010), The EU and the European Security Order: Interfacing Security Actors, London.

Berggruen N., Gardels N. (2013), The Next Europe: Toward a Federal Union, „Foreign Affairs”, Vol. 92, No. 4.

Berggruen, http://berggruen.org/about\#mission-statement (19.05.2016).

Buzan B. (2003), Regional Security Complex Theory in the Post-Cold War World, w: Theories of New Regionalism: A Palgrave Reader, (eds.) F. Söderbaum, T. M. Shaw, London.

Buzan B. i in. (1990), The European Security Order Recast: Scenarios for the Post-Cold War Era, London. 
Buzan B., Wæver O. (2003), Regions and Powers: The Structure of International Security, Cambridge.

Centre for European Policy Studies Thinking ahead for Europe_eu, https://www.ceps.eu/ (19.05.2016).

Deklaracja Schumana - 9 maja 1950 r. (2015), „Unia Europejska”, 1.12.2015. http://europa.eu/about-eu/basic-information/symbols/europe-day/schuman-declaration/index_pl.htm (19.05.2016).

Demurtas A. (2014), The EU Regional Security Complex between 2001 and 2011 in relation to the threat from Islamic terrorism and weapons of mass destruction, „ICIP Working papers”, No. 7, Barcelona.

EPC - European Policy Centre - Independent think tank_eu, http://www.epc.eu/ (19.05.2016).

EUobserver_com, http://euobserver.com/ (19.05.2016).

EurActiv_com - EU news and policy debates across languages_com, http://www.euractiv.com/ (19.05.2016).

EUROPA - EU Newsroom, http://europa.eu/newsroom/home_en (19.05.2016).

Europe Situation Reports Stratfor, http://www.stratfor.com/regions/europe/situation-report (19.05.2016).

Europe Without the Union (2016), „Geopolitical Weekly”, 1.03.2016, http://www.stratfor.com/weekly/ europe-without-union (19.05.2016).

Glossary of summaries - EUR-Lex, http://eur-lex.europa.eu/summary/glossary.html (19.05.2016).

Góralczyk B. (2014), Kryzys 2008 r. a nowa rola Unii Europejskiej na scenie globalnej, w: Unia Europejska jako aktor na scenie globalnej. Razem czy osobno?, (red.) B. Góralczyk, Warszawa.

Half of people in nine European countries believe UK will vote to leave the EU (2016), Ipsos MORI, 9.05.2016, http://www.ipsos-mori.com/researchpublications/researcharchive/3731/Half-ofpeople-in-nine-European-countries-believe-UK-will-vote-to-leave-the-EU.aspx (19.05.2016).

Hvidsten A. H., Hovi J. (2015), Why no twin-track Europe? Unity, discontent, and differentiation in European integration, „European Union Politics”, Vol. 16, No. 1.

Hyde-Price A. (2007), European Security in the Twenty-First Century: the Challenge of Multipolarity, London.

Intersecting Interregionalism: Regions, Global Governance and the EU (2014), (eds.) F. Baert, T. Scaramagli, F. Söderbaum, Dordrecht.

Joenniemi P. (2007), Towards a European Union of Post-Security?, „Cooperation and Conflict”, Vol. 42, No. 1, DOI: 10.1177/0010836707073479.

Kissinger H., Billington J. H. (2001), Does America Need a Foreign Policy? Toward a Diplomacy for the $21^{\text {st }}$ Century, New York.

Kostecki W. (1994), The Security Complex Approach. An Outline, „Working Papers”, No. 19/1994, Centre for Peace and Conflict Research, Copenhagen.

Kostecki W. (1996), Europe after the Cold War: The security complex theory, Warsaw.

Kostecki W. (2012), Strach i potęga. Bezpieczeństwo międzynarodowe w XXI wieku, Warszawa.

Kostecki W. (2014), Bezpieczeństwo Polski a dynamika stosunków międzynarodowych, w: Bezpieczeństwo Polski. Wspótczesne wyzwania, (red.) S. Wojciechowski, A. Potyrała, Warszawa.

Kuźniar R. (2016), Spadaj globalny policjancie. Co po Zachodzie?, „Gazeta Wyborcza”, 21.05.2016.

Lake D. A., Morgan P. M. (1997), Regional Orders: Building Security in a New World, University Park, Pa.

Laporte V. (2012), The European Union - an Expanding Security Community?, College of Europe, „EU Diplomacy Papers”, No. 6. 
Ławniczak K. (2014), Dezintegracja, konsolidacja czy status quo? Kryzys modernizacji w Unii Europejskiej a poszukiwanie nowego paradygmatu integracji, „Przegląd Europejski”, $\mathrm{nr} 4$ (34).

McSweeney B. (1996), Identity and Security: Buzan and the Copenhagen School, ,Review of International Studies", Vol. 22, No. 1, DOI: http://dx.doi.org/10.1017/S0260210500118467.

Nitoiu C. (2016), Aspirations to Great Power Status: Russia's Path to Assertiveness in the International Arena under Putin, „Political Studies Review” [opublikowany on-line przed drukiem 19.04.2016], http://psw.sagepub.com/content/early/2016/04/06/1478929915623967.full, DOI: $10.1177 / 1478929915623967$ (19.05.2016).

Nowak B. (2016), Trzeba myśleć szerzej, „Nowa Europa Wschodnia”, 4.05.2016, nr 3-4, http://csm.org.pl/pl/csm-w-mediach-2/1933-myslec-trzeba-szerze-artykul-dra-bartlomieja-nowaka-na-lamach-nowej-europy-wschodniej-4-05-2016 (19.05.2016).

Nygren B. (2008), The Rebuilding of Greater Russia: Putin's Foreign Policy Towards the CIS Countries, London.

Patrick S. M. (2015), The EU's Migration Crisis: When Solidarity and Sovereignty Collide, 9.09.2015, „The Internationalist”, Council of Foreign Relations, http://blogs.cfr.org/patrick/2015/09/ 09/the-eus-migration-crisis-when-solidarity-and-sovereignty-collide/ (19.05.2016).

Patrick S. (2016), An Ever-Looser Union: Can Europe Survive Its Current Crises?, „Foreign Affairs”, Snapshot, 29.03.2016, http://www.foreignaffairs.com/articles/europe/2016-03-29/ever-looser-union (19.05.2016).

Phinnemore D. (2013), The Treaty of Lisbon: Origins and Negotiation, Basingstoke.

Presidency Conclusions (2007), Brussels European Council 21-22 June 2007, Council of the European Union, 23 June.

Rieker P. (2006), Europeanization of National Security Identity: The EU and the Changing Security Identities of the Nordic States, London.

Should the European Union be a federation?, 19.09.2012, http://www.debatingeurope.eu/2012/09/ 19/should-the-eu-be-a-federation/ (19.05.2016).

Snetkov A. (2015), Russia's Security Policy Under Putin: A Critical Perspective, London.

Stewart-Ingersoll R., Frazier D. (2012), Regional Powers and Security Orders: A Theoretical Framework. Abingdon, Oxon.

The Nobel Peace Prize 2012, http://www.nobelprize.org/nobel_prizes/peace/laureates/2012/ (19.05.2016).

Toje A. (2010), The European Union As a Small Power: After the Post-Cold War, New York.

Wæver O. (1998), Insecurity, security, and asecurity in the West European non-war community, w: Security communities, (eds.) E. Adler, M. N. Barnett, Cambridge, UK.

Wćver O. (2005), The Constallation of Securities, w: Globalization, Security and Nation State: Paradigms in Transition, (eds.) E. Aydinli, J. N. Rosenau, New York.

With Ukraine, Europe is 'entering a more dangerous period', analyst says (2015), DW, 09.02.2015, $\mathrm{http} / /$ www.dw.de/with-ukraine-europe-is-entering-a-more-dangerous-period-analyst-says/ a-18245760 (19.05.2016).

Wojtaszczyk K. A., Nadolska J., Czub J. F. (2014), Kryzysy w procesie integracji europejskiej i sposoby ich przezwyciężania - wprowadzenie do problematyki badań, „Przegląd Europejski”, nr 3 (33).

World business, finance and political news from the Financial Times - FT_com Europe, http://www.ft.com/home/europe (19.05.2016).

Zakaria F. (2008), The Rise of the Rest, „Newsweek”, 3.05.2008. 


\title{
STRESZCZENIE
}

Myślą przewodnią artykułu jest próba naszkicowania narzędzia analitycznego, które usystematyzowałoby rozważania nad możliwymi wariantami rozwoju Unii Europejskiej w wyniku splotu okoliczności wewnętrznych i zewnętrznych. Pod uwagę brane są perspektywy dalszego postępu, zatrzymania i upadku integracji, oddziaływania postępowania Rosji i przemian w szerszym środowisku międzynarodowym. W tym celu wykorzystane zostało podejścia wypracowane przez wpływowy nurt badawczy, nazywany szkołą kopenhaską: teoria kompleksów bezpieczeństwa.

Słowa kluczowe: Unia Europejska, kompleks bezpieczeństwa, transformacja

\section{TRANSFORMATION OF THE EUROPEAN SECURITY COMPLEX}

\begin{abstract}
The main goal of the article is an attempt to outline an analytical tool that would systematize considerations of the possible variants of the development of the European Union as a result of a coincidence of internal and external circumstances. Prospects of further progress, stop, and fall of integration, impacts of the proceedings of Russia and changes in the broader international environment are taken into account. For this purpose an approach developed by the influential mainstream research, called the Copenhagen school, has been implemented: the theory of security complexes.
\end{abstract}

Key words: European Union, security complex, transformation 
